\title{
Getting Graphic with the Past: Graphic Novels and the Teaching of History
}

\author{
Michael Cromer \\ University of British Columbia \\ Penney Clark \\ University of British Columbia
}

\begin{abstract}
This article explores the potential of the graphic novel as a means to approach history and historiography in secondary school social studies and history classrooms. Because graphic novels convey their messages through the interaction of visuals and written text, they require reading that is across the grain. They have been likened to hypertext, a format with which students are increasingly familiar, because they are flexible and open-ended and can be approached in multi-layered ways, and read along both linear and nonlinear paths. This format holds promise for increasing students' tolerance of ambiguity and appreciation for the nature of history as interpretation.
\end{abstract}

\section{Introduction}

A new theatre of operations has opened in the American war on terror and the battle for the hearts and minds of the children of the Middle East-the Arab Street comic book. According to a March 28, 2005 posting on the Federal Business Opportunities website, the United States Army was looking for illustrators and writers to develop a comic book series for Arab youth. The advertisement stated, "In order to achieve long-term peace and stability in the Middle East, the youth need to be reached ... A series of comic books provides the opportunity for youth to learn lessons, develop role models and improve their education" (Description, p. 1). Known as "psy-op warriors," the Army's $4^{\text {th }}$ Psychological Operations Group based out of Fort Bragg does not have a history of success with comics in Iraq. In 1991, during the first Gulf War, leaflets showing soldiers thinking with thought balloons, common in American comic strips, were incomprehensible to many Iraqis. 
Nonetheless, social studies educators could think about the U.S. Army and its use of images combined with text as a pedagogical psy-op for their own classrooms. The popularity of graphic novels is soaring, with sales of $\$ 250$ million recorded in 2006 (Bouchard, 2006). No longer relegated to comic book shops, they are now found in mainstream bookstores. Recently, the venerable Art Gallery of Ontario mounted an exhibition featuring the work of Seth (who uses only one name professionally) and acquired his novel, $\mathrm{Hush}$, for its permanent collection (Farquharson, 2005).

Graphic novels are also finding their way into schools. Librarians have begun to stock them on their shelves with the aim of eventually luring young readers into the pages of more canonical novels. "Getting Graphic @ Your Library" was the theme of the 2002 Teen Read Week sponsored by the Young Adult Library Services Association (YALSA), a division of the American Library Association. In her online introduction to the event, librarian Francisca Goldsmith (2002) explained how literature in sequential art format could be powerful and deserving of critical attention. Since many of their avid readers are adolescents and teenagers, historical graphic novels present a promising opportunity for schools to promote student engagement with history.

In the introduction to a special issue of Rethinking History dedicated to the graphic novel, editors Hugo Frey and Benjamin Noys (2002) argue, "Although the graphic novel has largely remained beneath critical attention, the form has actually been the site for some sustained and sophisticated engagements with the problems of representing historical events" (p. 255). For Frey and Noys, the primary reason for scholarly interest in the graphic novel is to elevate it from its pulp fiction-like status, which, as a result of the cultural turn that opened the everyday to closer historical inquiry, has not tarnished other popular media. The lowly status of the graphic novel is somewhat surprising given the mixed nature of the medium- "text (without being novels) and images (without being films)" (Groensteen, 2000, p. 35) - and the recent recognition of hybridity as a way of looking at the Self and the Other and their variegated appearances in the past (Iggers, 1997).

This article points to the very recent journey of this genre towards cultural legitimacy and the unexplored, but very rich, potential it has for the teaching of history and historiography. There is little empirical research from which to draw regarding the efficacy of using graphic novels for the teaching of history in secondary schools. This article, then, has two aims. The first is to explore possibilities for including the graphic novel as a resource for the teaching of, and about, history. The second and more implicit aim is to highlight the need for empirical research related to its use in history classrooms. 


\section{Toward Legitimacy}

Will Eisner's 1978 Contract with God is generally considered to be the first graphic novel. Although the term had been used previously, it is the first time the label "graphic novel" appeared on a book cover. Possibly the most widely known graphic novel is Art Spiegelman's Maus: A Survivor's Tale, published in two parts in 1986 and 1991. Spiegelman's metaphorical account chronicles the removal of his parents from their comfortable life in Poland to the death camps of Auschwitz and Birkenau, and from there to a commonplace existence in upstate New York. This book may appear at first to be a simple comic with the Jews depicted as mice, the Nazis as cats, the French as frogs, and the Poles as pigs, but the power of the metaphors captures the reader almost immediately. It was acclaimed as a "quiet triumph ... impossible to achieve in any medium but comics" (Scholz, 1985, p. BW18).

It is significant to note that Scholz's 1985 review of Maus was in the "Children's Book" section of the Washington Post, thus highlighting the unique position held by the graphic novel as an artistic form. Legitimacy for the graphic novel has grown since then, and historians and educators, as well as the broader public, are beginning to recognize its value for representing the past. Spiegelman's "epic story told in tiny pictures" (Tucker, 1985, p. BR3) won a special Pulitzer Prize in 1992 and established the artistic, literary, and historical worth of remembering the past through the graphic novel. It "demonstrated that comics could handle the complexity of subjects like the Holocaust and personal memoir with as much sensitivity and intelligence as film or prose" (Sturm, 2002, p. 6).

Joe Sacco's graphic work that detailed his time in war-torn Bosnia, Safe Area Gorazde (2000), was described by David Rieff (2000) in The New York Times as "the best dramatic evocation of the Bosnian catastrophe.. . Of the myriad books that have appeared about Bosnia, few have told the truth more bravely than Sacco's" (p. 5). In the foreword to Sacco's Palestine (2002), Edward Said acknowledged the aesthetic and political potential of the graphic novel:

A political and aesthetic work of extraordinary originality, quite unlike any other in the long, often turgid and hopelessly twisted debates that have occupied Palestinians, Israelis, and their respective supporters. With the exception of one or two novelists and poets, no one has ever rendered this terrible state of affairs better than Joe Sacco. (p. iii)

In spite of the recognition awarded to certain representatives of the genre, such as Maus, there lingers in the public forum the notion that graphic novels "often lead a hole-and-corner life in specialist bookstores and have an aura of seediness and/or violence" (Mackey \& McClay, 2000 , p. 191). In the school context they are sometimes considered to be 
"insubstantial and disreputable" (Hajdu, 2004, p. 2) when compared to other literary forms. They are viewed as simply more substantial comics, both smeared with the same pulp-style paint brush. Tracy LeMoine, a Canadian middle school librarian, described her acquisition of graphic novels as an ambivalent acceptance of mediocrity: "I'd rather they read something than nothing. If I can at least get them inside the library, the chances that they will read something I like are higher" (quoted in Sokoloff, 2005, p. A3). Cathy Yusep, the librarian responsible for reviewing books for the Calgary Board of Education, advised librarians to order graphic novels but not to resort to comic books (Sokoloff, 2005). However, the division between the former and latter is not always clear.

It is useful to distinguish graphic novels from comics. Scott McLoud (1993) defines comics as "juxtaposed pictorial and other images in deliberate sequence, intended to convey information and/or to produce an aesthetic response in the viewer" (p. 9), but the same could be said for graphic novels. Francisca Goldsmith (2002) describes graphic novels as "image-and-word codependent works" (p. 2), but the same could be said for comics. Graphic novels, like comics, are a hybrid comprising both visual and print texts. The differences between the two can be found in their physical appearance, subject matter, and the length and complexity of the stories they tell. Comics are ephemeral in nature and tend to appear in two forms: the "strip" form found in daily newspapers, and the soft cover "book" form, which is episodic in nature. Their content is often light and humorous, although they may tell an ongoing story. Graphic novels are usually hardcover volumes that tell a richer and more extended story than comics. They also usually deal with weightier topics, although, like comics, their content can be fiction or nonfiction.

The semantic fencing that seeks to establish firm boundaries between comics and graphic novels is largely a North American preoccupation intended to rescue the cerebral latter from the muscle-bound former. In the introduction to The Graphic Novel, a collection of essays presented at the International Conference on the Graphic Novel at the University of Leuven, Belgium, Jan Baetens (2001) points out that the canonical status and emphasis put on the visuality of the graphic novel in Europe encourage scholars to ask interesting questions about contemporary society, art, and theory. Indeed, the anthology includes essays that use the work of Russian theorist Mikhail Bakhtin (Vice, 2001), German political philosopher Hannah Arendt (Frahm, 2001), and French sociologist Pierre Bourdieu (Tilleuil, 2001). Baetens (2001) explains that there is a "deeply rooted suspicion towards the medium in the American academy" and asserts that the term graphic novel "is used, at least theoretically, to make a clear-cut distinction between the 'good guys' and the 'bad guys', between comics pulp fiction and more or less high-art visual narratives in book-form whose ambition it is to save the literary heritage in an illiterate world" (p. 7). 
Increasingly, scholars in North America are less concerned with marking out genre boundaries and more interested in issues familiar to those in other media studies. What is surprising is how late comics and graphic novels have made this cultural turn. Less surprising is that, as with Cultural Studies generally, academic work devoted to comics and graphic novels found its initial momentum in Europe. Like jazz, comics and graphic novels required European appreciation to turn them into an art form deemed worthy of North American aesthetic and critical inquiry.

The cross-cultural translation of graphic novels has also taken place across the Pacific with the popularity of Japanese manga (comics) and anime (cartoon films) in the West. And although some works of Japanese animation have been criticized (and rightly so) for excessive violence and erotic portrayals of adolescent girls, many of the established classics in the genre speak of Japanese national identity in the inescapable fallout from atomic violence and post-World War Two American occupation. To look at graphic literature as a product of its time and place is to catch a glimpse of the political and cultural zeitgeist of a nation. As Allen Douglas and Fedwa Malti-Douglas (1994) state in their Arab Comic Strips: Politics of an Emerging Mass, "all comics are political" (p. 1).

\section{Constructing Meaning with Graphic Novels in Social Studies Classrooms}

Productive interactions with polysemic texts such as graphic novels require recognition of four crucial notions: time, intertextuality, visual literacy, and hypertextuality. This section discusses what Will Eisner (1985) calls the "grammar" of this coupling of text and graphics as well as approaches to decoding it. According to Margaret Mackey and Jill Kedersha McClay (2000), teachers too often underestimate the ability of students to interact with text in sophisticated ways:

Adolescents are great readers of picture books and other forms of graphic text. They are experienced in numerous polysemic forms of text, they're eager to read as insiders and get the joke, and they are perhaps the ideal audience for the kind of subversiveness that becomes possible when two semiotic systems work with and against each other. (p. 196)

\section{Time}

A different set of skills is required to read polysemic texts such as graphic novels than what is required for reading print texts. In graphic novels and other polysemic texts, the reader must seek a productive interaction of the written and visual texts in order to fully engage in the 
narrative that is offered. This requires time. Writer Rick Kleffel (2004), an avid reader of traditional print texts, describes how he had to learn to allow the extra time necessary for engagement to take place when reading graphic texts: "It took me a while to learn to slow down, a while longer to pace the panels, so that I could enjoy the visual progression of the story as well as the text-based plot" (p. 26). If students are to be successful at finding meaningful paths through polysemic texts, teachers must find the space in the crowded school day where this can be allowed to happen.

\section{Intertextuality}

The cultural studies notion of intertextuality is central to this process of engagement. Walter Werner (2004) reminds us that "whenever a pictorial image is read in terms of-or through, against, alongside-another image or a surrounding set of images and words, intertextuality is at work; meanings assigned to the image differ from those that would be drawn if it were interpreted in isolation" (pp. 64-65). In the case of graphic novels, "graphics intertwine with texts as primary meaning-bearers" (Mackey \& McClay, 2000, p. 191); the words are interpreted through the images and the images through the words. Goldsmith (2002) notes this intimate interplay between text and image:

Every picture (as well as the words) helps tell part of the story in a graphic novel. It is the dynamic format of image and word offered in combination that delivers meaning and enjoyment to graphic novel readers. Whether fiction or factual, graphic novels rely on visual components and verbal text to communicate. (p. 2)

In a graphic novel, the print is incomplete without the visual text, and the visual text is incomplete without the print. One form does not simply accompany and expand the meaning conveyed in the other; rather, the two are co-dependent, with each equally necessary to meaning-making. Patricia Storace (2005), in her review of the graphic novel Persepolis, says, "Either element would be quite useless without the other; like a pair of dancing partners, Satrapi's text and images comment on each other, enhance each other, challenge, question, and reveal each other" (p. 40).

\section{Visual Literacy}

Jeffrey Kunkle (2005), in a review of Art Spiegelman's most recent graphic novel, In the Shadow of No Towers, points out how Spiegelman's work is akin to the interactivity implicit in websites and CD-ROMs and how important it is that students acquire the visual literacy skills necessary to navigate these information sources. 
Mackey and McClay (2000) argue that, despite their apparent simplicity, graphic novels can open up challenging intellectual and emotional territory: "This dual identity of graphic texts in book form-both fixed and fluid-makes them powerful allies for learning some very sophisticated reading strategies" (p. 192). Goldsmith (2002) agrees, pointing out that these include not just reading of print text, but also

decod[ing] facial and body expressions, the symbolic meanings of certain images and postures, metaphors and similes, and other social and literary nuances teenagers are mastering as they move from childhood to maturity.... Like any other esthetic insightfulness, the ability to "read" images that portray character, mood, and tone must be developed through experience. (p. 2)

Mackey and McClay explain how the traditional divisions and structuring of the classic "waffle" (squares of equal size in a grid) format can be deliberately disrupted to further the thematic intentions of the illustrator. Several writers have pointed to the role of the gutters (spaces) between the panels of a graphic novel in relating the narrative. Goldsmith (2002) states that "the reader is called upon to understand what is happening in and between the sequences of images (the panels of a graphic novel)" (p. 2). The reader must read across the spaces and provide a context that is not made explicit. McLoud (1993) discusses six ways the gutters work to make connections between visual images: moment-to-moment (passage of time), action-to-action (one subject in a series of actions), subject-to-subject (one subject to another, while staying in the scene or idea), scene-to-scene (across distances of time and space), aspect-to-aspect (different aspects of one particular place, idea, or mood), and non sequitur (no logical relationship between panels) (pp. 70-72). He says "space does for comics what time does for film" (p. 7); the reader creates the sequence across the spaces. In this sense, according to Alan Purves (1998), "the writer and the reader work together to create meaning" (p. 240). This is made more complex by the tendency of some graphic novelists (e.g., Spiegelman) to disrupt the notion of the waffle format by, for example, varying the size and shape of the panels, as well as angling and overlapping them.

\section{Hypertextuality}

As Purves (1998) has pointed out, the sequence in which readers confront the words and image on the pages of a graphic novel "may be horizontal-vertical, or it may be circular, or (using arrows) a criss-cross or boustrophedon (the form of text that reverses itself at each line like 
the movement of an ox pulling a plow)" (p. 239). David Hajdu (2004) discusses how Art Spiegelman employs this nonlinear approach in In the Shadow of No Towers:

Five or six story segments or graphic elements in different styles-one running vertically, one in a large circle, one broken up into images laid out like snapshots on the floor-all play off one another in an effect that suggests the scattershot multiformity of the Web. (p. 10)

Pushing the boundaries of linear story-telling, graphic novels weave filmic techniques of movement with textual systems of representation-a hybrid form that Dresang (1999) refers to as "hand-held hypertext" ( $p$. 63). In fact, the graphic novel format is frequently likened to hypertext. Wendy Morgan and Richard Andrews (1999) define hypertext as

a text composed of blocks of words (whether phrases, lines, sentences, paragraphs, or sets of paragraphs), or images in a computer program, which permit them to be linked in such a way that a reader may follow any of a number of pathways ... Such texts can allow diverse materials to be juxtaposed in sometimes unexpected and always dynamic ways, as one follows a path to successive text 'nodes'. (p. 81)

Purves (1998) suggests that comics and graphic novels may even be an earlier form of hypertext:

(Comics) lead us to an appreciation of the icon and the image and its part in our making sense of the relations among objects, and they point to the ways by which the writer and the reader work together to make meaning. However, comics go further than that. They lead us back to an appreciation of the image as a positive and integral part of our use of written language; they reconnect us with the world of the picture and the icon... The new form of communication on and off screen is iconic. Because it is iconic, it causes us to rethink the iconic nature of texts as well as hypertext. (p. 240)

As with hypertext, the connections across the spaces of a comic (or graphic novel) may be either temporal or visual (Purves, 1998). Readers are free to read the panels in a range of ways that move them beyond the conventional configuration of words on a page. This freedom helps the reader to a greater understanding of the iconic nature of the text. It also assists student readers toward a greater comfort with open-endedness and a greater tolerance of ambiguity, when they are encouraged to recognize that readers will construct varied meanings from such hypertext-like configurations. 
This process involves a devolution of the locus of authority over the text, with the reader assuming some of that authority previously reserved for the author alone. Purves asks:

Where is authority over the text? Where is authority in the text? To whom or to what is there to be obedience? Who is the originator of influence? It would seem to be an anarchy... Has the author disappeared or receded in the world of hypertext? (p. 241).

And Wendy Morgan stated in an interview with Richard Andrews (1999):

A single, print text can be offered as something coherent and closed, finished and polished-a policy document, which has its own disembodied, authoritative voice from nowhere-the word from on high. To be able to break into that, create irruptions and eruptions-that's at the heart of critical literacy work. (p. 89)

\section{Implications for History Pedagogy}

Marci Singer Gabella (1994) reminds us that "the sources for understanding history exist in a far broader array of forms than typically made available to students in history classrooms" (p. 160). Although Gabella limits her discussion to painting, photography, music, poetry and film, graphic novels are another promising way to include other forms of representation in the teaching of history.

The transgression of boundaries, the spilling of ink outside the textual and graphic box, is where the graphic novel offers fruitful opportunities for the telling of history. This mutability of binary divisions is how Patricia Storace (2005) frames her review of Marjane Satrapi's two-volume Persepolis. The collection traces a privileged Iranian girl's childhood through the 1979 overthrow of the Shah, the triumph of the Islamic Revolution, the devastating effects of the eight-year war with Iraq, the difficult teenage exile to Austria, and her return to Tehran in 1998. As Storace explains, the cartoon world Satrapi creates in stark black and white ink is far from black and white:

Pictures function less as illustration than as records of action, a kind of visual journalism. On the other hand, dialogue and description, changing unpredictably in visual style and placement on the page within its balloons, advance frame by frame like the verbal equivalent of a movie ... It is not too fanciful to say that Satrapi, reading from right to left in her native Farsi, and from left to right in French, the language of her education, in which she wrote Persepolis, has found the precise medium to explore her double cultural heritage. (p. 40) 
Graphic novels that are rich and multi-layered are one means to help students appreciate the complexity of history. As Keith Barton (1996) points out, "any single story invariably involves selection, simplification, and distortion ... Much of the business of history, in fact, is argumentation over whose selective interpretation is best" (p. 403). Tidy and linear historical narratives belie the "messiness" of the past.

Frey and Noys (2002) explicate the value of exploring representations of history through the graphic novel: "What we mean by history in the graphic novel is how the graphic novel is a site where 'history' itself, or representations of history, are put into play: interrogated, challenged, and even undermined" (p. 258). They explain that "the particular hybrid form of the graphic novel might offer a testing place to probe the limits of history and historiography" (p. 259). As Renee Hobbs (2001) points out, the increasing diversity of information now available everywhere and to everyone has intensified the need to develop in students the skills required to be "citizens in an information age" (p. 411). As part of this constellation of sources, graphic novels offer a textual and visual reworking of traditional linear narratives.

Art Spiegelman's graphic novel, In the Shadow of No Towers (2004b), is a despairing and traumatic account of the intersection of the author's personal experience with the events of $9 / 11$ and the broader implications of those events. It also suggests how the graphic novel can be used to develop students' historical consciousness as it relates to acts of violence and terrorism. On September 11, 2001, Art Spiegelman and his wife witnessed the first plane crash into the World Trade Center, about ten blocks south of where they were standing, just outside their lower Manhattan apartment building. After a frantic search to find their daughter, a freshman among three thousand confused and terrified students at the ten-story Stuyvesant High School below the towers, they raced to the United Nations school to find their ten-year-old son.

The theme of In the Shadow of No Towers overlaps with his earlier graphic novel, Maus. It also complicates and disrupts attempts to find facile parity between the horrors of the past and those of today. In an interview, Spiegelman (2004a) explained, "I don't posit the scale of what was happening to me on 9/11 to what happened to my parents, but of course, there I was standing at the same juncture of personal and world history" (p. B9). So, as with Maus, he processes the ways in which world and personal histories collide. Ultimately, Speigelman constructs several strata of historical critique. The final 12 pages of this 42-page book are a sort of "supplement, reproducing seven vintage Sunday newspaper strips that dealt a century ago with war, patriotism, Arabs, Lower Manhattan, and buildings threatening to fall" (Hajdu, 2004, p. 8). Though this final section hints at a nostalgic longing for apparently simpler times in New York, it nonetheless attempts to respond to the pervasive post- 9/11 question, "Why do they hate us?" 
Spiegelman's work diverges from much of the artistic outpouring that tries to come to terms with $9 / 11$ and its global reverberations. In fact, as Michiko Kakutani (2004) points out, "while our therapeutic culture may want to subject all experience to simplistic 12-step procedures, closure vis-à-vis $9 / 11$ remains elusive, and the artistic efforts, which enshrine that closure, tend to feel hollow and forced" (p. E1). For this reason, "it is a testament to Art Spiegelman's uncompromising vision that 'In the Shadow of No Towers' ... makes no effort to contain or domesticate the surreal awfulness of that day" (p. E10). Spiegelman's unresolved trauma is conveyed as he repeatedly tries to recreate the image of the glowing skeleton of the North Tower moments before its collapse, finally accepting that he cannot adequately illustrate the traumatic site/sight. Kakutani suggests that the book's chaotic nature offers one aesthetic approach for grappling with the enormity of $9 / 11$ and notes that "words alone have proven curiously inadequate as a means of testimony" (p. E1).

In his review of In the Shadow of No Towers, Jeffrey Kunkle (2005) speaks directly to history teachers:

Both Spiegelman's first-person depiction of September $11^{\text {th }}$ and his use of turn-of-the-century comic strips provide high school students the opportunity to delve into the different ways in which events are recorded and interpreted ... It is a biased work, without question, but one of Spiegelman's points seems to be that any attempt to record history is inherently subjective and driven by ideological intent. (pp. 550-551)

The graphic novel as a medium is caught in a Möbius loop (Purves, 1998) relationship with the message it employs to speak about the past. As suggested by Storace (2005) in her review of the graphic novel, Persepolis, the interplay between image and text creates a fused narrative of singular impact. Additionally, the manifold configurations of this relationship facilitate readings of ambiguous, complex, and difficult moral questions. This ethics-based impact is strengthened by the interplay between image and text, intensifying the testimony of past violence through both story and picture. The current memory impetus requires a response from educators and students, and a responsibility to answer to (not necessarily for) past injustices.

Concepts of history must accommodate eruptions of multiple pasts into a narrative of the present. Since the last decades of the $20^{\text {th }}$ century, the obsession with progress and with what is to come have been supplanted by a focus on how the present is marked by its difference from what was. For Andreas Huyssen (2000), we have moved from a concern with "present futures to present pasts" ( $p$. 21). That is, current commitments to a future of nonviolence, a time 
of "never again," are sustained in part by defining the discontinuities between the sins of the past and the comparative virtues of the present. However, while these sins may be displaced by the passage of time, they are routinely practiced anew in the present. As the Rwandan genocide, for example, makes clear, "never again" was an empty turn of phrase. Huyssen argues that the current revival of memory studies is rooted in

our societies' need for temporal anchoring when, in the wake of the information revolution, the relationship between past, present, and future is being transformed. Temporal anchoring becomes even more important as the territorial and spatial coordinates of our late twentieth century lives are blurred or even dissolved by increased mobility around the globe. (p. 7)

This temporal disorientation and non-synchronous, mass-mediated world dislocate linear narratives and histories that propose progressive teleologies unmediated by the past. William Faulkner (1950) expressed it plainly in his oft-quoted remark: "The past is never dead. It's not even past" (p. 92).

Although we live with the traces of the past, we can never fully comprehend the motives and actions of people in the past or successfully contextualize events, because of the vast expanse of time between us that has fundamentally altered the circumstances in which we live (Ashby \& Lee, 1987; Seixas, 1996; Davis, 2001). Given that the form of the graphic novel allows for both linear and nonlinear readings, it holds great potential as a useful pedagogical resource to explore ways in which the past is with us, but at the same time, remains beyond our reach.

At least part of the role of history and social studies educators is to help students to begin to see ways in which their lives brush up against or collide with events of the past. In the case of $9 / 11$, although there may be insufficient historical or emotional distance to achieve an enduring artistic perspective, Kakutani (2004) argues that Spiegelman's In the Shadow of No Towers

feels like a harbinger of artistic works to come. Its frantic, collagelike juxtaposition of style; its repudiation of traditional narrative; its noisy mix of images and words; its trippy combination of reportage, fantasy, and paranoia all recall the most innovative works to come out of the Vietnam War. (p. 14).

The Holocaust and terrorist acts are far from the only topics that have been explored in graphic novels. I have already discussed works such as Joe Sacco's Palestine and Safe Area Gorazde, as well as Marjane Satrapi's Persepolis. Canadian history is also represented in this genre. For ex- 
ample, in Bannock, Beans, and Black Tea, graphic artist Seth (and Gallant) (2004) presents his father's stories of growing up in Prince Edward Island during the Great Depression. Although this book seems to be a very subjective history, it too offers social studies educators ways of politicizing and historicizing the personal within a broader historical context.

Chester Brown's Louis Riel: A Comic Strip Biography depicts Métis leader Louis Riel and the resistances he led against the Canadian government in the late $19^{\text {th }}$ century. Brown steps back from his narrative, providing in the book's conclusion a commentary about his decisions on the use of historical evidence. At one point he observes, "The way I've drawn this scene makes the conversation seem more casual than it probably was" (2003, p. 246). At another point, he provides two different versions, with their sources, of the words spoken to Riel by the hangman at his execution. His commentary raises compelling epistemological issues that provide a glimpse into the questions that historians ask of their sources and the ways they draw inferences. This is a powerful way to make students aware that history is merely the way we select from and choose to interpret the vast array of possibilities presented by the past.

There are enough graphic novels now that it is possible to compare the treatment of a particular historical topic, such as the Holocaust, by several different graphic novelists. Robert Eaglestone's (2002) nuanced comparative examination of Miracleman and Desert Peach, two very different novel series about the Holocaust, offers a model. Miracleman, a superhero series, presents a bystander account, while the perspective in Desert Peach is that of perpetrator. It should be noted that in Miracleman, "the Nazi Holocaust is continually implied but never actually mentioned" (p. 329). These novels are, in turn, compared to Arthur Spiegelman's Maus, a tale of survivors and of the imprint of survival on their son. He concludes that "the most garish and commonplace comic trope-the superhero [in Miracleman]contains the "more eloquent cipher of history'" (p. 329). Eaglestone suggests that the first two novels (and Maus by implication) "do not offer a history, as such, but a historiography, a way of reading (and writing) history" (p. 328).

This statement is not unique to graphic novels. It could be made about a representation of history in any form. The unique contribution that graphic novels can make to history pedagogy lies in their dual visual/written textual format. Because the written text is so limited in graphic novels, students can access it more easily than they can in more extensive accounts. Students may also be willing to attempt a deconstruction of visual accounts that is not as apparent when they are confronted with written texts. There may be an innate appeal in graphic novels (perhaps stemming from both their comic book heritage and their affinity with hypertext) that, for many students, is not 
present in accounts that rely solely on written text. Finally, an inherent ambiguity of the visual/text combined format of graphic novels lies in the multiple ways they can be read. Therefore, graphic novels provide an accessible format that may be highly useful for interpretation of the historiography of historical accounts in secondary school history classrooms.

Traditional Western historiography has generally privileged a single narrative (progress) and a single medium of pedagogic delivery (text). These a priori judgments of the relationship between facts and events have suffered the ill winds of postmodern critique. Nonetheless, as much as postmodernism has laid waste to the foundations of a pristine past, the primacy of the verbal and linguistic over the visual and unsaid remains intact. As bearers of meaning, graphic novels should not be viewed as diluted print texts or as supplementary to written renderings of the past.

Mackey and McClay (2000) illustrate the "central clash between the apparent safety of elements of the form and the terrifying focus of the content... This clash makes room for open readings" (p. 196). Similarly, the examples we choose for exploring history and memory offer no comfort or closure, exposing students as they do to the subjective nature of stories of the past. For example, Art Spiegelman's In the Shadow of No Towers does not answer the perennial question about the motives of the $9 / 11$ terrorists. It is in this absence of a ready answer where the pedagogical potential of his artistic rendering of $9 / 11$ lies.

Werner (2002) points to the importance of a supportive classroom community, where students can engage in discussions of meanings that may be ambivalent and contested. Such a community allows them to enlarge their own ideas as they consider and build on those of others. Discussion turns the classroom into a communal space where new ideas are provoked, minds are changed, and interpretive horizons are expanded. It is the primary instructional means by which individuals clarify, extend, and challenge textual interpretations. Through the synergy of hearing and responding to other readings, participants come to realize that any single reading is partial and limited, that no single meaning exhausts possibilities or brings closure.

One way to approach this in the classroom is to present students with a series of questions about some historical events with which they are familiar and then have them use their responses to construct narrative accounts. They are then asked to read a graphic novel account of the events, engage in discussion of that narrative, and then construct written narratives based on the graphic novel. The original narratives can be compared with those of other students, then with the graphic novel narratives. Students can draw conclusions about historiography and historical accounts based on their creation and reading of the various narratives. 
Following is a suggested question sequence about a particular series of events with which students are familiar. These questions pertain primarily to the concept of historical significance (Seixas, 1994):

- What were the main events and in what sequence did they occur?

- Who were the people involved? Who exercised agency and in what ways?

- Who has been omitted from the account we are beginning to construct?

- Describe relevant aspects of the larger historical context of these events.

- Why have historians judged these events as significant enough to include in the historical record of this time period?

- Write a narrative of these events.

Here is a question sequence to follow the reading of a graphic novel version of the same events:

- What are the main events and in what sequence did they occur?

- Who were the people involved? Who exercised agency and in what ways?

- Who has been omitted from this account?

- From whose perspective is this narrative told?

- Describe relevant aspects of the larger historical context of these events.

- What literary devices are used to drive this narrative, and how are they used (e.g., metaphor, exaggeration)?

- How do the visuals and the written text complement/contradict one another?

- Is there more than one story told here? Would you call these stories competing or complementary stories?

- Write the narrative of these events as they are presented in the graphic novel.

Students can compare their narratives and then continue the questioning:

- In what ways did your first narrative differ from that of other students?

- In what ways did your narrative based on the graphic novel differ from other students?

- In what ways did your first narrative differ from your second?

- From whose perspective(s) has each narrative been told?

- What can we conclude about historiography and historical accounts from examination of these narratives? 
While the appeal of graphic novels may be immediately apparent to students, their limitations may not. It can be helpful to compare a graphic novel account with other graphic novel accounts, as I discussed earlier. Students can also gain insights into how history is written-that is, the diverse inferences historians must draw in order to craft complex and nuanced accounts-by comparing a graphic novel account with other kinds of narratives. These might include a textbook, a painting, a trade book account written for a public audience, a collection of annotated journal entries, a documentary, or a docudrama.

Students could begin to explore the possibilities and limitations of each medium for presenting the past in ways that are true to the primary sources and that acknowledge the need for nuance and complexity. They might then be ready to develop a set of criteria that could provide a rich way to adjudicate various representations of history. The list should be viewed as a work-in-progress, which students could modify as they continue to encounter representations of history throughout the school year.

\section{Conclusion}

The graphic novel is a relatively recent concept that is highly promising for engaging secondary school students in history and historiography. It is an inviting resource for them because its multilayered, nonlinear structure is comparable to the hypertext format with which most young people are familiar. The graphic novel format allows them to access the text in various ways beyond what the traditional linear format of print texts can offer. It also encourages students to marry print and visual representations in order to read in ways that are deeply meaningful, because the narrative is incomplete without both dimensions.

Graphic novels can provide opportunities to engage students with history in ways that may encourage them to become more critical consumers of historical accounts. The inherent ambiguity in the visual/text format of graphic novels opens up possibilities for multiple readings and interpretations of their content. This process can develop students' appreciation for the challenges involved in constructing nuanced and complex historical accounts in ways that are true to the primary sources on which they are based. Experiences with graphic novels can help students to develop an understanding of the immense challenges of historiography, to problematize the locus of authority in historical accounts, and to deepen their understanding of history as interpretation.

Author Note

This article is dedicated to the memory of Michael Cromer (1973- 2005). Michael was an extraordinary doctoral student in the Centre for the Study of Historical Consciousness, University of British Columbia, at the time of his sudden death. He is sorely missed. 


\section{References}

Ashby, R., \& Lee, P. (1987). Children's concepts of empathy and understanding in history. In C. Portal (Ed.), The history curriculum for teachers (pp. 62-88). London, UK: Falmer.

Baetens, J. (2001). Introduction: Transatlantic encounters of the second type. In J. Baetens (Ed.), The graphic novel (pp. 7-9). Leuven, Belgium: Leuven University Press.

Barr, D. (1991on). Desert Peach. Seattle, WA: MU Press.

Barton, K. (1996). "Everybody knows what history is ..." Research, instruction, and public policy in the history curriculum: A symposium. Theory and Research in Social Education, 24, 391-415.

Bouchard, G.A. (2006, December 30). Graphic novels come into their own. Edmonton Journal. Retrieved March 20, 2007 from http://www.canada.com

Brown, C. (2003). Louis Riel: A comic strip biography. Montréal, QC: Drawn and Quarterly.

Davis Jr., O.L. (2001). In pursuit of historical empathy. In O.L. Davis Jr., E.A. Yeager, \& S.J. Foster (Eds.), Historical empathy and perspective taking in the social studies (pp. 1-12). Oxford, UK: Rowman \& Littlefield.

Douglas, A., \& Malti-Douglas, F. (1994). Arab comic strips: Politics of an emerging mass culture. Bloomington, IN: Indiana University Press.

Dresang, E.T. (1999). Radical change: Books for youth in a digital age. New York: H.W. Wilson.

Eaglestone, R. (2002). Madness or modernity?: The Holocaust in two Anglo-American comics. Rethinking History, 6(3), 319-330.

Eisner, W. (1985). Comics \& sequential art. Tamarc, FL: Poorhouse Press.

Eisner, W. (1996; 1978). A contract with God and other tenement stories. New York: DC Comics.

Farquharson, V. (2005, June 28). Drawn into the high art world. National Post, p. B1.

Faulkner, W. (1950). Requiem for a nun. NY: Random House.

Federal Business Opportunities. (2005, March 28). 76-Comic book. Retrieved April 16, 2005, from http://www.fedbizopps.gov/index.html

Frahm, O. (2001). "These papers had too many memories. So I burned them". Genealogical remembrance in Art Spiegelman's Maus. A survivor's tale. In J. Baetens (Ed.), The graphic novel (pp. 61-78). Leuven, Belgium: Leuven University Press.

Frey, H., \& Noys, B. (2002). Editorial: History in the graphic novel. Rethinking history (6) 3, 255-260.

Gabella, M.C. (1994). The art(s) of historical sense. Journal of Curriculum Studies, 27(2), 139-163.

Gallant, J., \& Seth. (2004). Bannock, beans and black tea: Memories of a Prince Edward Island childhood in the Great Depression. Montreal: Drawn \& Quarterly.

Goldsmith, F. (2002). Get graphic @ your library: An introduction. Retrieved May 2, 2005, fromhttp:/ / www.ala.org/yalsa/teenreading/trw2002.htm.

Groensteen, T. (2000). Why are comics still in search of cultural legitimization? In A. Magnussen and H-C Christiansen (Ed.), Comics and culture (pp. 29-41). Copenhagen: Museum Tusculanum.

Hajdu, D. (2004, September 12). Homeland insecurity [Review of the book In the shadow of no towers]. The New York Times, 7(13).

Hobbs, R. (2001). Media literacy skills: Interpreting tragedy. Social Education, 65(7), 406-411.

Huyssen, A. (2000). Present pasts: Media, politics, amnesia. Public Culture, 12, 21-38.

Iggers, G.G. (1997). Historiography in the twentieth century: From scientific objectivity to the postmodern challenge. Middletown, CT: Wesleyan University Press.

Kakutani, M. (2004, August 31). Portraying 9/11 as a Katzenjammer catastrophe. [Review of the book In the shadow of no towers]. The New York Times, p. E1.

Kleffel, R. (2004, Dec. 31). Words \& pictures: $A$ readers' guide to reading graphic novels. Retrieved February 16, 2006 from www.trashotron.com/agony/columns/2004.

Kunkle, J. (2005). Standing in the shadows of history. Review of In the shadow of no towers. Theory and Research in Social Education, 33, 548-552.

Mackey, M., \& McClay, J. K. (2000). Graphic routes to electronic literacy: Polysemy and picture books. Changing English, 7(2), 191-201. 
McLoud, S. (1993). Understanding comics. New York: HarperCollins.

Moore, A., Leach, G., \& Davis, A. (1985on). Miracleman. Guerneville: Eclipse Books.

Morgan, W., \& Andrews, R. (1999). City of text? Metaphors for hypertext in literary education. Changing English, 6(1), 81-92.

Purves, A. (1998). Flies in the web of hypertext. In D. Reinking, M.C. McKenna, L.D. Labbo, \& R.D. Kieffer (Eds.). Handbook of literacy and technology: Transformations in a post-typographic world (pp. 235-251). Mahwah, NJ: Lawrence Erlbaum.

Rieff, D. (2000, December 24). Bosnia beyond words. [Review of the book Safe Area Gorazde]. The New York Times, 7(1), p. 5.

Sacco, J. (2000). Safe area Gorazde. Seattle, WA: Fantagraphics.

Sacco, J. (2002). Palestine. Seattle, WA: Fantagraphics.

Said, E. (2002). Homage to Joe Sacco. Palestine. Seattle, WA: Fantagraphics.

Satrapi, M. (2003). Persepolis: The story of a childhood. New York: Pantheon.

Satrapi. M. (2004). Persepolis 2: The story of a return. New York: Pantheon.

Scholz, C. (1985, November 10). Comic books: Philosophy in a small balloon. [Review of the book Maus: A survivor's tale]. The Washington Post, p. BW18.

Seixas, P. (1994). Students' understanding of historical significance. Theory and Research in Social Education, 22(3), 281-304.

Seixas, P. (1996). Conceptualizing the growth of historical understanding. In D.Olson \& N. Torrance (Eds.), Handbook of education and human development: New models of learning, teaching, and schooling (pp. 765-783). Oxford, UK: Blackwell.

Seth. (1999). Hush. Toronto: Art Gallery of Ontario.

Sokoloff, H. (2005, April 25). Librarians turn to comic books. The National Post, p. A3.

Spiegelman, A. (1986). Maus I: A survivor's tale: My father bleeds history. New York: Pantheon.

Spiegelman, A. (1991). Maus II: A survivor's tale: And here my troubles began. New York: Pantheon.

Spiegelman, A. (2004a, August 7). A comic book response to $9 / 11$ and its aftermath. The New York Times, p. B9.

Spiegelman, A. (2004b). In the shadow of no towers. New York: Pantheon.

Storace, P. (2005, April 7). A double life in black and white. [Review of the books Persepolis: The story of a childhood and Persepolis 2: The story of a return]. The New York Review of Books 52(6), 40-43.

Sturm, J. (April 5, 2002). Comics in the classroom. The Chronicle of Higher Education. Retrieved February 16, 2006 from www.teachingcomics.org/curriculum/chronicle.php.

Tilleuil, J-L. (2001). Narrative specularity and sociocritical stakes in the contemporary French-speaking comic strip production. In J. Baetens, (Ed.), The graphic novel (pp. 145-155). Leuven, Belgium: Leuven University Press.

Tucker, K. (1985, May 26). Cats, mice and history-The avant-garde of the comic strip. [Review of the book Maus: A survivor's tale]. The New York Times, p. BR3.

Vice, S. (2001). "It's about time": The chronotope of the Holocaust in Art Spiegelman's Maus. In J. Baetens (Ed.), The graphic novel (pp. 47-60). Leuven, Belgium: Leuven University Press.

Werner, W. (2002). Reading visual texts. Theory and Research in Social Education, 30(3), 401-428.

Werner, W. (2004). "What does this picture say?" Reading about the intertextuality of visual images. International Journal of Social Education, 19(1), 64-82.

MICHAEL CROMER was a PhD student in the Centre for the Study of Historical Consciousness at the University of British Columbia, Vancouver, British Columbia, Canada V6T 1Z4.

PENNEY CLARK is Associate Professor in the Department of Curriculum Studies at the University of British Columbia, Vancouver, British Columbia, Canada V6T 1Z4. 
Copyright of Theory \& Research in Social Education is the property of National Council for the Social Studies and its content may not be copied or emailed to multiple sites or posted to a listserv without the copyright holder's express written permission. However, users may print, download, or email articles for individual use. 